\title{
SOME REMARKS ON THE CLAIMED ARAB AUTHORSHIP OF THE CANTAR DE MIO CID
}

\author{
ALGUNAS OBSERVACIONES SOBRE \\ LA ATRIBUCIÓN DE AUTORÍA ÁRABE \\ DEL CANTAR DE MIO CID
}

JAmes T. Monroe University of California, Berkeley. USA

In a recent book entitled El Cantar de mío Cid: génesis y autoría árabe, ${ }^{1}$ Professor Dolores Oliver Pérez argues that that famous Castilian epic was written by an Arab author, namely the learned jurist, scholar and poet Abū 1-Walīd al-Waqqašì (408/1017-489/1096), who was born in Huecas, a small town in the province of Toledo, who became an admirer and close friend of Rodrigo Díaz de Vivar after the latter had conquered Valencia, and who composed the heroic poem in his friend's honor.

There is, however, at least one compelling reason why Professor Oliver Pérez's theory on the Arab authorship of the Cantar de mio Cid ${ }^{2}$ cannot be accepted in its present form: in the early twenties of the previous century, the American scholar Milman Parry became interested in the so-called "Homeric question" and, in order to understand certain mysteries posed by the Greek epic tradition, such as that of how a minstrel could possibly memorize poems as long as the Iliad and the Odyssey in order to recite them orally, he and his student Albert B. Lord went to what was then Yugoslavia, and conducted extensive fieldwork interviewing and studying Serbo-Croatian oral epic minstrels

${ }^{1}$ Oliver Pérez, Dolores, El Cantar de Mio Cid: génesis y autoría árabe, Almería, Fundación Ibn Tufyal, 2008.

${ }^{2}$ Henceforth abbreviated $C M C$. 
(guslari). ${ }^{3}$ As a result of their findings, they produced what has come to be known as the Parry-Lord theory of oral-formulaic composition. According to this theory, which has radically altered our approach to, and understanding of, the oral epic and genres related to it, the SerboCroatian epics were anonymous (i.e., they were not "authored" by any given individual, but instead, their plots were handed down orally among illiterate minstrels, from teacher to student) and, with each new recitation of the poem, they were improvised by using the technique of formulaic composition, rather than being memorized. When Parry and Lord interviewed the actual singers, the latter all insisted that it was their custom to recite the songs literally, without changing the wording in any way whatsoever, but when recordings of their performances were made, it became apparent that each individual performance (be it by a given poet, or by a different one) was, in fact, worded differently from all others, and that the poems could be longer or shorter, including or leaving out episodes, depending upon the time allotted to each singer. In conclusion, it became obvious that these singers, being illiterate, had only a vague idea of what a word was. The researchers discovered, moreover, that the singers relied, in singing their tales, on a large number of word groups that could be repeated in specific metrical positions. These, Parry and Lord called formulas, and came to the conclusion that the singers were speaking in formulas, rather than in individual words. By stitching together specific formulas, each of which had a given metrical value, in the proper order, they were able to produce metrically regular lines of verse.

The findings of Parry and Lord, which these two scholars discovered by directly observing the way living epic singers actually worked, set off a remarkable wave of studies on the oral traditions of numerous literatures worldwide, both on the epic and on related poetic genres. Specifically, Joseph J. Duggan applied these findings to the study of Old French and Spanish epics. ${ }^{4}$ In his research, Professor

3 The results of their investigations are conveniently summarized in Lord, Albert B., The Singer of Tales, Cambridge, Mass, Harvard University Press, 1960.

${ }^{4}$ Among his many works on the Old French epic, see, Duggan, Joseph J., The Song of Roland: Formulaic Style and Poetic Craft, Berkeley, University of California Press, 1973. On the $C M C$ specifically, see, Duggan, Joseph J., "Formulaic Diction in the Cantar de mio Cid and the Old French Epic," Forum for Modern Language Studies, 10 (1974), pp. 260-269; Duggan, Joseph J., The Cantar de mio Çid: Poetic Creation in its Economic and Social Contexts, Cambridge [Eng.]-New York, Cambridge University Press, 1989. 
Duggan relied on the use of computers, with which he was able to compile word-in-context concordances of the various epics he studied. In these concordances, all occurrences of any given word-group that were repeated within any specific poem could be listed alphabetically, so that the poem's formulas could be easily identified. As a consequence, if any epic in particular, included a high percentage of formulaic diction, it could be safely concluded that it had been orally improvised, whereas, on the contrary, if the proportion of formulas was low, it could be assumed that it was a text that had been composed by a literate poet.

In contrast to Colin Smith, who had previously argued that the $C M C$ was written by a literate author, namely Per Abbat, the copyist of the only extant MS of the poem, ${ }^{5}$ Joseph Duggan showed that its high proportion of formulas could only indicate that it was the product of oral-formulaic improvisation. By now, it is thus abundantly clear that the $C M C$ is an anonymous work; that, as such, it was orally composed by means of formulaic improvisation, and transmitted by illiterate minstrels, rather than having been "authored" by any literate individual.

Nevertheless, and despite Duggan's remarkable contribution to $C M C$ studies, current scholarly opinion is still divided between those who believe that the poem was orally improvised, à la Parry-Lord, and those who do not. ${ }^{6}$ One of the most recent studies to reject the oral-formulaic approach to the $C M C$, accompanies two editions of that text by Alberto Montaner. ${ }^{7}$ Montaner categorically dismisses any and all relevance of the Parry-Lord theory to the $C M C$, proposing instead, that a learned minstrel first composed the text in writing, so that it could be memorized and recited orally at a later date. ${ }^{8}$ This assumption - and it is no more than an assumption - overlooks or, at very least, minimizes seven major points, to wit:

5 Smith, Colin, The Making of the Poema de Mio Çid, Cambridge [Eng.]-New York, Cambridge University Press, 1983.

${ }^{6}$ On this subject, see the recent overview of scholarship on the subject by Wright, Roger, "Hispanic Epic and Ballad," in Reichl, Karl (ed.), Medieval Oral Literature, Berlin-Boston, De Gruyter Press, 2012, pp. 411-427.

7 Cantar de mio Cid, edición, prólogo y notas de Alberto Montaner; estudio preliminar de Francisco Rico, Barcelona, Galaxia Gutenberg, 2007; Cantar de mio Cid, edición, estudio y notas de Alberto Montaner, con un ensayo de Francisco Rico, Barcelona, Biblioteca Clásica de la Real Academia Española, 2011.

${ }^{8} C M C$, ed. Montaner, 2011, p. 304. 
(1) It has been amply demonstrated that the text of the $C M C$ is based on formulaic diction, a technique that is typical of illiterate, oral improvisers. Were this not so, it would be difficult to understand how a poem that is 3,730 lines long, could have been memorized by a literate poet. The fact that literate poets sometimes repeat themselves, adduced by Montaner in support of his claims, has nothing to do with the significantly higher degree of repetition found in oral compositions. In the latter, the repetitions are integral to the method of composition, and therefore functional, whereas in the former they are often mistakes that violate the learned rhetorical principle of horror aequi.

(2) Much has been written about the $C M C$ 's notorious metrical irregularity. In this respect, we are on safe grounds in assuming that a literate poet would not have composed his work to so irregular a beat, unless he were a very poor poet, unable to keep count of his syllables, which the composer of this great masterpiece of Spanish literature obviously was not. Instead, such metrical irregularities are typical of oral improvisation. As Professor Lord pointed out, the guslari he interviewed and recorded, all adhered to a regular meter, as long as they were singing their poems. But when asked to dispense with musical accompaniment, and merely recite their epics, they seemed to be at a loss, and to produce metrically irregular lines of verse. This would seem to suggest that the extant MS text of the $C M C$ is a scribal transcription of a song-text dictated without the accompaniment of melody. However, the oft-noted fact that the $C M C$ is irregular in its versification, has also been explained, by myself (relying on certain findings made by Professor Bridget Connelly, on whom see, below), as being a direct result of its oral delivery: ${ }^{9}$

\begin{abstract}
After tape-recording the performances of several Egyptian singers of the Ban $\bar{u}$ Hilāl epic cycle, [Bridget Connelly] used a stopwatch to measure the length of time it took to sing each line of verse, and observed that each singer had his own preferred and optimal time-length, which was always fixed and regular, even when the number of syllables varied from one line to the next. It turned out to be the case that it was the melody alone, that allowed the singer to stretch or contract his irregular number of syllables so as to fit them within a regular time-
\end{abstract}

9 See Monroe, James T., "Tracing the Remnants of a Romancero Tradition Among Andalusī Muslims and Their Morisco Descendants," in Martín, Adrienne L. and MartínezCarazo, Cristina (ed.), Spain's Multicultural Legacies-Studies in Honor of Samuel G. Armistead, Newark, Del., Juan de la Cuesta, 2008, pp. 159-197. 
unit. In this instance, an empirical observation made, in the field, for Arabic oral epic, by Professor Connelly, allows us to understand, if only by analogy, what may have caused the metrical irregularity of the Spanish $C M C$, for which we can no longer attend or witness oral performances. ${ }^{10}$

Either of these two possibilities (or perhaps even both of them together) would fit the case of the $C M C$. On this basis, it is hard to believe that the $C M C$ is a composition authored by a literate poet, since such a poet, presumably with his eye glued to the page, would have paid far greater attention to the requirements of meter.

(3) Numerous scholars have commented on how the $C M C$ interweaves history, (not to speak of geography) with fiction. ${ }^{11}$ Although the poem, which is anonymous, cannot be dated with any degree of certainty (these being two further symptoms, if not outright indications, of oral composition), it appears to have been composed no later than a century after the events narrated in it took place. ${ }^{12}$ Similarly, it did not rely on written sources such as the Historia Roderici. ${ }^{13}$ Clearly, a learned poet would have followed such sources, and adhered more strictly to historical events and geographic realities, than we find is the case with the $C M C$. In contrast, it is reasonable to suppose that an illiterate poet would have felt free to introduce fictional events into his composition in order to impress his audience which, as Francisco Rico shows, consisted of illiterate commoners, rather than members of a learned upper class. ${ }^{14}$ In this respect, the famous episode known as the "afrenta de Corpes" is instructive: in the $C M C$, the Cid's two daughters appear with the names of Elvira and Sol respectively; in real life, their names were María and Cristina. In the poem, they marry the two cowardly infantes counts of Carrión who, in real life, never existed. As a result, an episode central to the poem, namely the "afrenta de Corpes," in which the two fictional husbands first mercilessly beat, and then abandon their wives, in order to shame and dishonor the Cid, in actual fact, never took place. The episode was, instead, clearly invented by an illiterate minstrel, unrestrained by historical reality, in order to illustrate the Cid's

${ }^{10}$ Monroe, "Tracing the Remnants," p. 169.

${ }^{11} C M C$, ed. Montaner, 2011, pp. 228, 237-238, 270, 275.

${ }^{12} C M C$, ed. Montaner, 2011, pp. 246, 249, 258, 281.

${ }_{13} C M C$, ed. Montaner, 2011, p. 238.

${ }^{14}$ CMC, ed. Montaner, 2011, p. 221. 
extraordinary mesura ('self control'), insofar as that character, instead of seeking personal vengeance against the perpetrators of this outrage against his daughters, is portrayed as seeking justice through proper legal means.

(4) It has been claimed that the knowledge of legal and court proceedings on the part of the $C M C$ 's composer indicates that he was a learned personality rather than an illiterate individual. This is not necessarily so for, in a largely illiterate society, such as that of medieval Europe, court proceedings, which were conducted in public, would have been familiar even to the illiterate observers of such proceedings. Furthermore, one is entitled to ask whether a jurist versed in the principles and proceedings of Islamic Law, such as alWaqqaši, would have been equally versed in those of Roman and Germanic Law that are reflected in the $C M C$. At the beginning of the poem, for example (11. 23-28), a royal order ('carta') for the Cid to be exiled from Castile arrives in Burgos. We are first told that it is firmly sealed ('fuertemientre sellada', 1. 24), and only then are we informed of its contents (11. 25-28). What seems calculated to impress the minstrel's illiterate audience is the official seal on the document, whereas its contents are secondary.

(5) As I have indicated elsewhere, the late Álvaro Galmés de Fuentes pointed out a similarity between the famous ballad "Muerto yace ese buen Cid * que de Vivar se llamaba..." and an episode in the Sirat 'Antar, in both of which works the hero appears on the battlefield after his death. Professor Galmés used this coincidence as an argument in favor of his theory on the influence of the Arabic epic tradition on that of Spanish. But, as I also pointed out, the motif of the dead hero fighting on the battlefield to defend his followers, or covering a retreat for the latter, is one that is universal to the epic tradition, and is also found in Latin, Old French, Hindi, Bantu, and Old Irish. Therefore, we can only wonder if, in the case of 'Antar and the Cid, we are not dealing with a universal epic motif rather than an instance of direct genetic influence of Arabic on Spanish. ${ }^{15}$ What, for the present purpose, is of far greater interest, is that this particular ballad episode, also narrated in Alfonso el Sabio's Primera crónica general de España, ${ }^{16}$ does not appear in the $C M C$. If we

${ }^{15}$ See Monroe, "Tracing the Remnants," pp. 157-170, 185-191.

${ }^{16}$ Menéndez Pidal, Ramón et al. (ed), Primera crónica general de España, Madrid, 
subscribe to Ramón Menéndez Pidal's theory, today accepted by most scholars, that ballads are the result of the fragmentation of epics, we might venture to suggest that this episode, concerning the postmortem exploits of the Cid, derives from some other epic improvisation on the Cid, today lost, within an oral tradition in which epics, like their ballad counterparts, "lived in their variants."

(6) Galmés also suggested that the metrical irregularity of the $C M C$, to which reference has been made above, reproduces the lines and rhymes of Arabic saj ' ('rhymed prose'), ${ }^{17}$ a suggestion to which I offered several objections. ${ }^{18}$ For example, if what Galmés had in mind was the rhymed prose of the extremely learned Arabic maqāmāt ('picaresque works') or rasā'il ('literary epistles'), it would be hard to imagine that an illiterate bard, composing in Spanish, could have been familiar with such compositions. On the other hand, there is one famous work in Arabic, couched in rhymed prose, that, as my late colleague, the folklorist Alan Dundes showed, is highly formulaic in nature, and that, as the Islamic tradition maintains, was revealed to an illiterate ('umm $\vec{\imath}$ ) prophet, namely Muhammad. This work is no less than the Qur'ān itself, in which the term $u m m \bar{\imath}$ is applied to the Prophet five times. ${ }^{19}$ It happens to be the case, however, that several contemporary western scholars have challenged this meaning of the word $u m m \bar{\imath}$ and suggested others instead, among them, 'member of the umma' ('Islamic community'). ${ }^{20}$ Nevertheless, the strikingly formulaic nature of the $Q u r^{\prime} \bar{a} n$, as demonstrated by Professor Dundes, allows us to conclude, in support of traditional Islamic belief, that the Prophet was indeed illiterate. Thus, it seems to be clear that, if Homer, along with many other composers of great works, was illiterate, there is little reason to assume that the improviser of the $C M C$ was a learned bard, or that a poem 3,730 lines long was written by

Gredos, 1955, chaps. 955-956, pp. 636-638.

${ }_{17}$ Galmés de Fuentes, Álvaro, Épica árabe y épica castellana, Barcelona, Ariel, 1978, pp. 147-150; see, too, Galmés de Fuentes, Álvaro, La épica románica y la tradición árabe, Madrid, Gredos, 2002.

${ }_{18}$ See Monroe, "Tracing the Remnants," p. 169.

${ }^{19}$ See Dundes, Alan, Fables of the Ancients? Folklore in the Qur'ann, Lanham, Rowman and Littlefield Publishers, 2003, "Oral-Formulaic Theory," pp. 15-23; "Oral Formulas in the Qur'ān," pp. 23-54.

${ }^{20}$ See the discussion in Geoffroy, E., "Ummī," in Gibb, H. A. R. (ed.), et al., The Encyclopaedia of Islam: New Edition, Leiden, Brill, 1979-2004, vol. 10, pp. 863b-864a. 
a learned author in order, first to be memorized, and then recited orally.

(7) It has been noted that the $C M C$ 's diction is full of linguistic forms that were already archaic in their own day. ${ }^{21}$ Once again, this phenomenon is characteristic of oral-formulaic composition, in which such forms tend to become frozen within set formulas. This is so, because, when a linguistic form changes, it may alter the formula metrically, by adding, or suppressing, syllables within it, thereby rendering it unusable in context.

In light of the seven points outlined above, we can only conclude, in the words of the proverbial saying, that "if it walks like a duck, and quacks like a duck, it must be a duck."

More recently, and in Arabic literature itself, oral-formulaic composition has also been discovered: (A) in the pre-Islamic qașida, by Michael J. Zwettler ${ }^{22}$ and myself, ${ }^{23}$ thereby refuting the thesis of Tāhā Husayn ${ }^{24}$ and D. S. Margoliouth, ${ }^{25}$ according to which, Pre-Islamic poetry had been forged by later poets who flourished in the Islamic period. (B) As far as the Arabic epic is concerned, its contemporary manifestations have been studied directly, in Egypt, and in the field, by Bridget A. Connelly, ${ }^{26}$ Susan Slymovics, ${ }^{27}$ and Dwight F. Reynolds, ${ }^{28}$ whereas their medieval forms, which have survived only in prose transcriptions, as exemplified by the Sirat 'Antar and other heroic narratives, have been studied by Peter Heath, ${ }^{29} \mathrm{H}$. T. Norris, ${ }^{30}$

${ }^{21}$ CMC, ed. Montaner, 2011, p. 284.

${ }^{22}$ Zwettler, Michael J., The Oral Tradition of Classical Arabic Poetry: Its Character and Implications, Columbus, Ohio State University Press, 1978.

${ }_{23}$ Monroe, James T., "Oral Composition in Pre-Islamic Poetry," JAL, 3 (1972), pp. 1-53.

${ }^{24}$ Husayn, Tāhā, $F \bar{l} l$ l-Ši ' $r$ al-Jāhilī, Cairo, Maṭba'at Dār al-Kutub al-Mișriyya, 1926; Husayn, Ṭāhā, Fì l-Adab al-Jāhilī, Cairo, Mațba'at al-I'timād, 1927.

${ }^{25}$ Margoliouth, D. S., "The Origins of Arabic Poetry," Journal of the Royal Asiatic Society, n.v. (1925), pp. 417-449.

${ }^{26}$ Connelly, Bridget A., Arab Folk Epic and Identity, Berkeley, University of California Press, 1986.

27 Slymovics, Susan, The Merchant of Art: An Egyptian Hilāà Oral Epic Poet in Performance, Berkeley, University of California Press, 1987.

${ }^{28}$ Reynolds, Dwight F., Heroic Poets, Poetic Heroes: The Ethnography of Performance in an Arabic Oral Epic Tradition, Ithaca, N. Y, Cornell University Press, 1995.

${ }^{29}$ Heath, Peter, The Thirsty Sword: Sirat 'Antar and the Arabic Popular Epic, Salt Lake City, University of Utah Press, 1996.

${ }^{30}$ Norris, H. T., The Adventures of 'Antar, Warminster, Wiltshire, Aris and Phillips, 1980.

Al-Qanțara XXXIII 2, 2012, pp. 553-562 ISSN 0211-3589 doi:10.3989/alqantara.2012.005 
and Malcolm C. Lyons. ${ }^{31}$ Even more recently, an oral, storytelling tradition, as it has survived today in the Maghreb, has been studied by Richard Hamilton. ${ }^{32}$ Let it be noted, however, that this tradition is largely one of poetry composed through improvisation, by illiterate bards, whose oral-formulaic technique differs by far from that of learned Arab poets such as al-Waqqašì. The widespread nature of orally improvised, colloquial Arabic, heroic verse and related genres, over time, thus strongly suggests that it may also have existed in Andalus. Although no epics of this sort have so far been discovered there, it is instructive to note that several lengthy 'arājizz ('poems in the rajaz meter'), clearly epic in content, are mentioned by Andalusī authors, while one of these has actually survived, namely that of Ibn 'Abd Rabbihi. ${ }^{33}$ This poem, which is couched in classical Arabic, may well be a literate imitation of others from a lost oral tradition, that were couched in the colloquial Arabic diction of the Iberian Peninsula.

To return to Professor Oliver Pérez's claims, it would seem clear to all but a few contemporary scholars, that the $C M C$ is an anonymous epic poem, orally improvised by illiterate minstrels, through the use of formulaic diction, and orally transmitted, while the proof of all this rests upon the very significant discoveries made by Professors Parry and Lord in the fields of oral literary theory and criticism, along with the application of these discoveries to the $C M C$ by Professor Duggan. Therefore, and unless their theory is entirely wrong (and here, the opponents of this theory have yet to come up with more convincing arguments than the groundless assumptions they have so far provided in support of their case), the $C M C$ could hardly have been "written," or "authored" by anyone. The poem's improvisational nature may also help to explain why those versions incorporated into the Primera crónica general de España and the Crónica

${ }^{31}$ Lyons, Malcolm C., The Arabian Epic: Heroic and Oral Storytelling, Cambridge [Eng.]-New York, Cambridge University Press, 1995, 3 vols.

${ }^{32}$ Hamilton, Richard, The Last Storytellers: Tales from the Heart of Morocco, London-New York, I. B. Tauris, 2011.

${ }_{33}$ Al-'Iqd al-Farīd, Amīn, Ahmad (ed.), Cairo, Lajnat al-Ta'līf wa-1-Tarjama wa-1Našr, 1962, vol. 4, pp. 501-527; English translation in Monroe, James T., Hispano-Arabic Poetry: A Student Anthology, Piscataway, NJ, Gorgias Press, 2004, pp. 74-129. Studied in Marcos Marín, F., Poesía narrativa árabe y épica hispánica, Madrid, Gredos, 1971, and Monroe, James T., "The Historical Urjüza of Ibn 'Abd Rabbihi: A Tenth-Century Hispano-Arabic Epic Poem,” JAOS, 91 (1971), pp. 67-95. 
de veinte reyes differ considerably, not only from one another, but also from that contained in the Per Abbat manuscript, since all three versions may well have been based upon different improvisations made either by the same or by different minstrels.

In light of the above, it follows logically that the Castilian $C M C$ could not have been "authored" by anyone, least of all by a learned Arab poet, contrary to what Professor Oliver Pérez argues. Nevertheless, that author ends her otherwise remarkably learned book by describing it as "un trabajo que consideramos inacabado." ${ }^{34}$ Given the exemplary open-mindedness of such a scholarly approach, one can only hope that she will continue her study of the fascinating subject she has chosen to investigate, while at the same time taking into account the comments and suggestions herein respectfully submitted, in what I hope is a constructive way.

Recibido: 02/02/2012

Aceptado: 18/04/2012

${ }^{34}$ Oliver Pérez, El Cantar de Mío Cid, p. 384. 